\title{
THE FAMILY ASSISTANT'S ROLE IN SUPPORTING FAMILIES WHOSE PARENTAL AUTHORITY HAS BEEN LIMITED
}

\begin{abstract}
AвSTRACt. Rajewska de Mezer Joanna, The Family Assistant's Role in Supporting Families whose Parental Authority has been Limited [Rola asystenta rodziny we wspieraniu rodzin z ograniczonymi prawami rodzicielskimi]. Studia Edukacyjne nr 51, 2018, Poznań 2018, pp. 183-200. Adam Mickiewicz University Press. ISSN 1233-6688. DOI: $10.14746 /$ se.2018.51.10
\end{abstract}

With its specific way of functioning and network of interweaving interactions of various character and emotional intensity, the family is an environment where the process of a child's socialization takes place, social personality develops and patterns of social roles are acquired. A family that malfunctions can trigger deviation mechanisms, thus considerably contributing to a child's social maladjustment. Due to that, in case the criteria described by law are met, it is necessary to use specific assistance measures and interfere in a family's autonomy, limit its parental authority and support it in fulfilling educational and socialization functions. Appointing a family assistant is one of the measures of limiting parental authority aimed at helping a family.

Key words: family assistant, family support, family assistance, social work with families, family dysfunction

When analysing the educational condition of contemporary families and their participation in the process of educating their children, we scrutinize children's parents who execute their parental authority and who are responsible for the course of socialization processes and shaping their offspring as social individuals.

Recently, families have been experiencing more and more various types of dysfunctions. This issue has become more burning in the face of the continuously increasing number of families that do not perform their tasks appropriately as far as raising their children is concerned. For instance, they do not look after their offspring appropriately, transmit negative patterns of social roles and act to the detriment of their children as a result of diverse 
forms of abuse or negligence. The change in the way how families function is substantially influenced by social and economic changes that take place in the state. Due to these, the previously well-functioning families become dysfunctional or pathological. ${ }^{1}$ This is often caused by their members' insufficient professional or social competences, which makes it impossible for them to overcome difficulties related to the change in employment conditions or inability to adjust to the requirements of the contemporary employer.

As a child's educational environment that exerts undeniable influence over the shaping of their personality and social attitudes, the family remains to be in the centre of interest of various fields of science and practice. As the smallest society-building cell, and at the same time a structure of an important socialization role, the family needs to be constantly focused on. It is especially the case in the face of the changing rules of functioning of the contemporary man in times when priorities are modified and previous values are deprecated.

The notion of the family has been defined and analysed many times. The definition of the family proposed by T. Szlendak ${ }^{2}$ is worth noticing, as it is an attempt at combining three traditions of describing the family: the modernist cell model that underlines the possession and socialization of the child, the evolutionary family model where the mother-child pair is the basis both for genetics and family life, and Simmel-Trost's postmodernist model of dyad. ${ }^{3}$

With its specific way of functioning, network of interweaving interactions of various character and emotional intensity, the family can trigger deviation mechanisms, thus considerably contributing to the origin of a child's social maladjustment. One should thus pay attention to its significance and functions in the process of a child's socialization.

As a child's primary educational environment, the family exerts a considerable influence over how they are shaped. From the pedagogical perspective, it is perceived as an environment and educational system, socializing and educational institution and emotional and cultural community. ${ }^{4}$ The developmental context is prominent for the notion of the family and especially important for the development of an individual in their early childhood. It

${ }^{1}$ M. Świderska, Asystent rodziny - wspótczesna forma pomocy rodzinie, Łódź 2013, p. 5.

2 T. Szlendak, Socjologia rodziny. Ewolucja, historia, zróżnicowanie, Warszawa 2012, p. 113 and $n$.

${ }^{3}$ The dyad is a group that dissolves when one of its members leaves or diep. The family is a group where there is at least one of the dyads: parent-child or partner-partner. According to Trost, the dyad model makes it possible to define the family since a dynamic family structure appeared in the Western culture - J. Trost, Family from a Dyadic Perspective, Journal of Family Issues, 1993, 14, 1, p. 102, quoted after: T. Szlendak, Socjologia rodziny. Ewolucja, historia, zróżnicowanie, Warszawa 2012, p. 110-111.

${ }^{4}$ D. Lalak, T. Pilch (Eds.), Elementarne pojęcia pedagogiki społecznej i pracy socjalnej, Warszawa 1999, p. 236. 
also refers to developmental changes and transformations in the mentality and behaviour of a juvenile in the later periods of ontogenesis, ending in adulthood. This context influences a person's growth, equipping them with the ability to learn from people whom they are socially and emotionally linked to. ${ }^{5}$ The family are not only the child's parents, but also other meaningful people (grandparents, siblings) who stay in close contact with them and have an undeniable influence on their biological and social development. ${ }^{6}$ One can thus say that the family is a group of relatives, next-of-kin, friends and other people gathered around the parent (most often the mother) and their child. ${ }^{7}$

Due to the topic of these considerations, it is worth underlining the importance of the family in a child's socialization process, its responsibility for transmitting the patterns of social roles, shaping their individual and social identity and attitudes towards the norms that are binding in the society. The family is called the basic agenda of socialization in the subject literature. ${ }^{8}$ Socialization is of multifaceted character as it is a complex process of learning which results in a human being becoming a social individual and a member of a given community (society).

With the socialization process, "(...) an individual gets used to the way of life of their group and a wider society by learning their rules and ideas included in the culture",${ }^{9}$ acquires the features of a social person, shapes their subject competences that make it possible to function and settle in the structure of a given social system, identify oneself in it and with it, and thus participate in the society as is expected and accepted. ${ }^{10}$ In the process of primary socialization and by means of mirroring, which is one of its mechanisms, children take over social patterns that are often undesired in the cross-generation transmission. Frequently, these patterns result in the child coming into conflict with the norms that are binding in the society.

In the course of socialization, one's personality is also shaped. The individual learns and acquires skills that are the basis for any social interactions, including norms, patterns of behaviour, emotional reactions and values. ${ }^{11}$

${ }^{5}$ B. Harwas-Napierała, Rodzina jako wartość w rozwoju człowieka, Poznań 2009, p. 13-14.

${ }^{6} \mathrm{~J}$. Rajewska de Mezer, Rola poradnictwa specjalistycznego we wsparciu rodziny w funkcji wychowawczej, [in:] Młodzież między ochrona a ryzykiem. Wspieranie rozwoju oraz pomoc psychologicznopedagogiczna dla adolescentów i adolescentek, Eds. B. Jankowiak, A. Matysiak-Błaszczyk, Poznań 2017, p. 186.

7 T. Szlendak, Socjologia rodziny, p. 114.

${ }^{8}$ Ibidem.

9 P. Sztompka, Socjologia. Analiza społeczeństwa, Kraków 2003, p. 286-287.

${ }^{10} \mathrm{~J}$. Modrzewski, Konformizm i dewiacja w doświadczeniu socjalizacyjnym jednostek i w ich spotecznej kwalifikacji, [in:] Socjalizacja dysocjacyjna w doświadczeniu indywidualnym i społecznym. Inspiracje teoretyczne i próby pedagogicznych ingerencji, Eds. A. Matysiak-Błaszczyk, J. Modrzewski, Poznań - Kalisz 2012, p. 24.

${ }^{11}$ B. Szacka, Wprowadzenie do socjologii, Warszawa 2003, p. 138. 
As part of socialization, the individual is submitted to various types of influence whose aim is to adapt them to the social conditions in a given environment. In spite of a large impact of parents who influence their children by educating them in an "intended and ordered" way, most of any socialization activities are unintended. One can thus say that socialization is a joint result of all intended and unintended types of influence. ${ }^{12}$

Due to the above, socialization can be presented in a narrower and wider way. In the narrower approach, it is understood as some spontaneous processes of social adjustment, whereas education that it is contrasted with is treated as intended and planned interaction with the object of education. On the other hand, in the wider approach, education and socialization are treated as processes that remain in the relation of superiority and inferiority with each other, yet education is a part of socialization that is a process of a broader meaning. For the process of socialization, the mechanisms that it is based on are important: reinforcement (i.e. rewarding appropriate behaviour and punishing inappropriate one), mirroring (consisting in similar behaviour repeated after others) and the mechanism of symbolic messages that consists in verbal cautions that are included in written texts. ${ }^{13}$

Socialization takes place all life and during its course the man learns new patterns of behaviour, corrects and modifies them based on their experience in order to live up to social expectations that they face. Configurations of patterns of behaviour that refer to various positions which people occupy in communities are called social roles. ${ }^{14}$

The family where an individual is socialized is a crucial and important factor in shaping their conduct and attitude towards abiding by social and legal norms. If those who are authorities for the child, the so-called "meaningful others", educate them in a way that is contradictory to the accepted social norms, they shape negative attitudes towards respecting the social and legal order in the child. With the above-mentioned socialization mechanisms, mirroring in particular, the child takes over some patterns of social roles and ways of reacting to situations that they are not comfortable with due to their lack of acting competence. K. Hurrelman claims that acting competence is a state of an individual skill to enter interactions with one's social and material environment, and build strategies of conduct, interaction and communication that make it possible for the individual to take appropriate action and coordinate the requirements posed by social situations. ${ }^{15}$ On the other hand,

\footnotetext{
12 T. Szlendak, Socjologia rodziny, p. 215.

13 B. Szacka, Wprowadzenie do socjologii, p. 138.

14 Ibidem, p. 139.

15 K. Hurrelmann, Struktura społeczna a rozwój osobowości. Wprowadzenie do teorii socjalizacji,
} Poznań 1994, p. 126. 
the risk of incorrect behaviour appears when the individual lacks appropriate acting competence, and its self-concept that is the basis for building identity becomes distorted due to the existence of a given pattern of personal and environmental features. ${ }^{16}$

Due to the topic taken up for consideration, a question arises of how to influence the family, cooperate with it educationally, support it in the process of shaping its offspring in order to diagnose educational problems that occur in it and counteract the demoralization of the juvenile early enough.

Another issue is to what extent and on what basis should the family autonomy be interfered in at the early stage of an educational problem that in the future may result in a child's social maladjustment, taking into account the need to apply the principle of subsidiarity. These questions should be answered based on the analysis of the actual state.

Once an answer to the significant questions mentioned above has been found, it is possible to shape or modify the interactions towards the juvenile and their family. These interactions are aimed at blocking the progress of undesired phenomena and creating a system for prevention and resocialization based on the cooperation among various institutions with the educational environment of the family.

Contemporary families are more and more frequently diagnosed with inappropriate completion or incompletion of the functions that are ascribed to them. In the past, the family would provide the individual with a starting cultural identity, having influence over their later experiences. Following the political and social changes of the turn of the centuries, the family, once fulfilling protective and defensive functions related to the core values that are culturally popular, focused on economic and existence functions, thus neglecting the cultivation of the cultural canon. Cultural transmission in the family depends on the conditions, norms, methods and measures used by parents and grandparents who bring the child up. ${ }^{17}$

The factors that characterize contemporary life conditions, in particular the anonymity of the individual in the society, have led to limiting the important control function of the family. The isolation of the family from its social surroundings and the increase in family privacy is at the same time accompanied by an increase in the importance of the emotional and expressive functions. ${ }^{18}$ One can notice that members of the contemporary family are

${ }^{16}$ Ibidem, p. 141-144.

${ }_{17} \mathrm{~J}$. Nikitorowicz, Rodzina w procesie ksztattowania tożsamości kulturowej w dobie regionalizacji i globalizacji, [in:] Wspótczesne rodziny polskie - ich stan i kierunek przemian, Ed. Z. Tyszka, Poznań 2004, p. 81-82.

${ }_{18}$ G. Cęcelek, Rodzina - jej problemy oraz zagrożenia wychowawcze, Mazowieckie Studia Humanistyczne, 2005, 1-2, p. 247. 
autonomized, which is a part of the process of family individualization. At present, norms and rules that family roles are based on are not transmitted as a long-lasting family legacy. To an increasing extent, the family ceases to be a lasting corrective structure that supports the process of creating one's own life path by the child. ${ }^{19}$ In spite of dynamic changes in the way the family, family relations and its functions are defined, the family remains to be the primary socialization environment that significantly influences the way the individual is shaped.

There are many types of family dysfunctions that originate from: parents' educational inefficiency, parents' loss of influence and authority, multiple addictions, parents' excessive engagement in professional work and the related "emotional abandonment of the child", or lack of employment (and the related inability to satisfy the family's needs or adopt social roles such as e.g. that of an employee). When incorrect patterns of behaviour, reactions and attitude to norms are transmitted to children in a dysfunctional family, there is a risk that they might be copied and lead to social maladjustment.

Social maladjustment of a juvenile is sometimes caused by the lack of parents' appropriate care and control due to their educational inefficiency or lack of educational activity. However, the leading role in transmitting negative patterns is taken over by the peer group responsible for triggering disorganizing mechanisms. According to the assumptions of Judith Rich Harris's group socialization theory, children educate themselves by participating in games in their peer groups. Behavioural features of individuals are shaped in the specific environment of their peer group. According to the author, the family, however, is only responsible for equipping children with a set of best genes and making sure that kids grow in "good health".$^{20}$ Aware of the influence and frequently demoralizing character of the peer and school environment on the development and shaping of the child, one asks oneself the question of the meaning of family activities as a counterbalance for the negative effects of peer influence. To what extent can the socialization influence of the family counterbalance the moulding influence of peer groups?

Being aware of the multiple causes of the incorrect functioning of the contemporary family that leads to social maladjustment and demoralization of children, one is required to support the family in completing its functions in a multifaceted and interdisciplinary way. This will allow to improve the situation of the child and make it possible to prevent the process of social maladjustment. The above-mentioned support, however, has to be provided

19 A. Żurek, Swoi i obcy w rodzinie, [in:] Rodzina wobec wyzwań wspótczesności. Wybrane problemy, Eds. I. Taranowicz, S. Grotowska, Wrocław 2015, p. 58.

20 J.R. Harris, Geny czy wychowanie? Co wyrośnie z naszych dzieci i dlaczego, transl. A. Polkowski, Warszawa 1998, quoted after T. Szlendak, Socjologia rodziny, p. 32-33. 
in a professional way, respecting family autonomy and its right to bring up children according to its own convictions. ${ }^{21}$

In line with the Family Law Act, parents should look after the physical and spiritual growth of the child that remains under their parental authority when they bring them up. They are assigned with the task to properly prepare their child to work for the good of the society according to their talents. ${ }^{22}$ In particular, parental authority encompasses parents' duty and right to be responsible for the person and wealth of the child, and for bringing the child up while respecting their dignity and rights. What is more, parental authority should be executed as required by the child's good and social interest. ${ }^{23}$

It is acceptable for the state to interfere in the autonomous activities of a family towards their child only in a situation where parents take inappropriate and detrimental care of their child.

The basis for taking up interfering activities is the leading principle of family law, i.e. the principle of the child's good. It is applied when interpreting regulations linked to i.a. the relation between a parent and their child. State activities are thus supposed to be aimed at protecting the child and their rights, and their objective is to counteract the child's demoralization which may occur in the family environment or in a demoralized peer environment in case there is no parental activity of tutelary or protective character.

The Constitution of the Republic of Poland gives priority to the family when it comes to bringing up the child. Yet, it allows to undertake action and interfere in the family autonomy as far as its educational functions are concerned in situations and under conditions defined in given acts of law. The act of law that details the above-mentioned issue is the previously quoted Family Law Act. ${ }^{24}$

Family law regulations provide for three forms of interference in parental authority: suspension of parental authority, deprivation of parental authority and limitation of parental authority. The decision to apply a given formal action that limits parents in their activities towards their children in various dimensions of life depends on the type, scope and consequences of the irregularities diagnosed. ${ }^{25}$

The suspension of parental authority is justified by a transient obstacle in exercising it. The notion of a transient obstacle refers to a situation where

\footnotetext{
${ }^{21}$ Art. 48 of the Constitution of the Republic of Poland of 2 April 1997 (Journal of Law 1997, No 78, item 483).

${ }^{22}$ Art. 96 of the Family Law Act of 25 February 1964 (Journal of Law 2017 item 682 with changes).

${ }_{23}$ Art. $95 \S 1$ and 3 of the Family Law Act of 25 February 1964 (Journal of Law 2017 item 682 with changes).

${ }^{24}$ Family Law Act of 25 February 1964 (Journal of Law 2017 item 682 with changes).

${ }^{25}$ J. Rajewska de Mezer, Rola poradnictwa specjalistycznego we wsparciu rodziny, p. 191.
} 
parents are temporarily unable to execute the tasks that result from exercising parental authority and these circumstances do not disqualify parents. ${ }^{26}$

The deprivation of parental authority is the most serious form of interference in parental authority over a child. For the court to justify adjudicating this measure, there has to be a permanent obstacle that makes it impossible for parents to execute their authority, abuse of the authority due to physical or psychological violence, or gross negligence towards one's child. ${ }^{27}$

A circumstance that allows to apply the third form of interference in parental authority, i.e. limitation of parental authority, is a state of threat for the child's well-being, and the aim of the action taken is to correct the family situation. ${ }^{28}$ Limitation of parental authority consists in decreasing and reducing it by depriving parents of some competences towards their child depending on the need diagnosed as far as custody, managing their wealth and representing them are concerned. When adjudicating in a given case, the family court adjusts the measure of limitation of authority to individual circumstances. The measures provided for in art. 109 of the act have different levels of interference in family life and parents' ability to make decisions for their child - from a court obligation for parents to carry out their functions appropriately; to the need to cooperate with a family assistant, undergo treatment or therapy, appointing a guardian to execute parental authority; to isolating the child from their parents by placing it in foster care in another family or institution.

The aim of interfering in the execution of parental authority over the child is to protect their well-being from negative consequences of their parents' actions or negligence. What has to be underlined is that the above forms of interference in parental authority do not constitute a sanction (punishment) as defined by criminal law. They are supposed to be a path for correcting a family situation, encouraging parents to appropriately execute their tasks that are a consequence of their authority, and thus protecting the well-being of their child and their right to grow in a sense of security while having their biological and emotional needs satisfied.

When referring to the specific forms of limiting parental authority, one should focus on the commitments that are imposed on the parents and controlled by the family and juvenile court that are meant to help parents and direct them in their actions. The court's actions provide institutional influence on the functioning of the educational system of the family. Noticing the need to support a family in executing parental authority and having

${ }^{26}$ Ibidem, p. 153.

27 Art. 111 of the Family Law Act of 25 February 1964 (Journal of Law 2017 item 682 with changes).

${ }^{28}$ M. Andrzejewski, Prawo rodzinne i opiekuńcze, Warszawa 2014, p. 154-155. 
diagnosed its deficits, the family court can oblige parents to act in a given way. ${ }^{29}$ One of those duties that I would like to focus on due to the topic of this paper is the duty of the family to cooperate with the family assistant that they have been assigned with.

The institution of the family assistant appeared in Polish legal regulations along with the act on Family support and system of foster care. ${ }^{30}$ It was a reaction to the need to support families that experience difficulties in executing their custody and educational functions with assistance that would be of a bigger scope and more accessible time-wise than previously.

The duty to cooperate with the family assistant is one of the measures of limitation of parental authority, ${ }^{31}$ adjudicated by family and juvenile courts in case there are educational problems in the family that justify the interference in its autonomy.

The family assistant can also be assigned to support a family by the manager of a social welfare centre that operates on a given territory in case there is information that the family experiences difficulties in executing its custody and educational functions. In the above circumstances, a social worker is obliged to carry out a community interview with this family. ${ }^{32}$ If the analysis of the evidence gathered indicates that there is a need to assign the family with help in this form, the manager of the welfare centre appoints an assistant for the family upon a social worker's request. Above all, the assistant works with the family where it lives, but also where it indicates them to. They are supposed to support the family that experiences difficulties in fulfilling custody and educational functions. Having analysed the family situation and the source of its problems, the family assistant should undertake action aimed at reinforcing the family's role and function in developing their custody and educational skills and increasing parents' awareness as far as their functioning in given social roles is concerned.

Family assistants take over social work from social workers with families where there is a number of overlapping problems of different origin (educational inefficiency, poor custody and educational skills, deficit of competences in managing a household, family violence, addictions, illnesses). This leads to an increased risk for the appropriate execution of custody and may lead to

${ }^{29}$ Art. 109 § 2 point 1 of the Family Law Act of 25 February 1964 (Journal of Law 2017 item 682 with changes).

30 Act of 9 June 2011 on Family support and system of foster care (Journal of Law 2017 item 697 with changes).

31 Art. 109 §2 point 1 of the Family Law Act of 25 February 1964 (Journal of Law 2017 item 682 with changes).

32 Art. 11 item 1 of the act of 9 June 2011 on Family support and system of foster care (Journal of Law 2018 item 998 with changes). 
depriving parents of their custody of the child. ${ }^{33}$ This is why one of the main problems of social work is the threat to the functioning and growth of the family resulting from its internal dynamics of development, as well as from the social and economic situation and cultural influence at the same time. ${ }^{34}$

One of the legal duties imposed on the family assistant is to design and carry out a plan of work with the family submitted to their custody. The plan should be designed in cooperation with family members, and with the approval of the social worker who supports the family. ${ }^{35}$ When a family starts to be supported by social welfare institutions, it is important for social worker operating where the given family lives and the appointed assistant to cooperate. The cooperation consists in exchanging information and creating interaction jointly based on a professional diagnosis of the problems of the given family. The family assistant has more time ${ }^{36}$ that they can devote to its members and thus focus on the specific problems of the given family and support it to solve the issues. Unlike the social worker, the assistant does not grant benefits of financial character, and their activities consist in a widely understood social work with the client and their family. The family assistant is focused on taking up activities towards the people they support that are not financial in nature (social work, counselling). Due to this, it is possible to avoid situations where the supported people cooperate with other helping entities exclusively encouraged by the possibility of being granted financial benefits. The legal solutions adopted by lawmakers in this respect force the family assistant to offer non-material encouragement to the people they support so that they make efforts aimed at solving the problems they face in life.

Work objectives set for family assistants depend on family deficits diagnosed and the need for it to achieve competences of a given scope. Sometimes families do not have the skill of running a household correctly. Many supported families require help in solving social (e.g. life, accommodation) or psycholo-

33 I. Krasiejko, Nowa rola asystenta rodziny, [in:] Pomoc społeczna wobec rodzin. Interdyscyplinarne rozważania o publicznej trosce o dziecko i rodzinę, Ed. D. Trawkowska, Toruń 2011, p. 268 and $\mathrm{n}$.

34 E. Wysocka, Warsztat diagnostyczny pracownika socjalnego w obszarze pracy z rodzina oraz przedmiotowe i podmiotowe uwarunkowania procesu diagnozy środowiska rodzinnego, [in:] Pomoc społeczna wobec rodzin. Interdyscyplinarne rozważania o publicznej trosce o dziecko i rodzinę, Ed. D. Trawkowska, Toruń 2011, p. 195-196.

35 Art. 15 item 1 of the act of 9 June 2011 on Family support and system of foster care (Journal of Law 2018 item 998 with changes).

36 According to art. 110 item 11 of the law of 12 March 2004 on social assistance (Journal of Law 2018 item 1508 with changes), one social worker who is employed full-time can provide social work to no more than 50 families and single-person householdp. On the other hand, according to art. 15 item 4 of the act of 9 June 2011 on Family support and system of foster care (Journal of Law 2018 item 998 with changes), within the same time a family assistant can work with no more than 15 families, and the number of families that they are appointed with depends on the level of difficulty of the tasks performed. 
gical problems, or issues related to bringing up children. One of the family assistant's tasks aimed at helping the family is to provide individual educational consultations for parents. ${ }^{37}$ Families that benefit from social assistance are very often characterised with parents' educational ineffectiveness, i.e. inability or irregularities in their execution of parental authority. Resulting from the lack of knowledge or competence, and sometimes from deliberate actions aimed at violating the child's rights, negligence can consist in unsatisfying their physical and emotional needs, do them harm in various dimensions of existence and require external interference. This interference is essential in that it not only makes it possible to stop the undesired actions by parents towards their child, but it also allows to work with them for them to change their perception of the child, their rights, thus resulting in correcting the way of executing parental authority. These actions make it possible to correct the patterns of social roles transmitted to children in the process of socialization, whereas the correct course of this process is vital for counteracting the process of a juvenile's social maladjustment.

As part of working with a family with the objective to help it execute custody over the child in an appropriate way that protects the child's rights, the family assistant should motivate parents to participate in group classes aimed at shaping correct parental patterns and psychosocial skills ${ }^{38}$. Effective actions taken in this area make it possible to create conditions for the correct course of the child's socialization process. They are a sort of assistance to self-help parents to execute their functions correctly. With their participation in the meetings, parents become aware of the problem that they tackle.

The family assistant also provides children with support which consists in making it possible for them to participate in psychoeducational classes. It is important for children with various problems (related to emotions, adaptation, education etc.) who come from families that need help in educational functions to be able to count on other's interest and professional assistance.

Another task of the family assistant is to support family's social activity, motivate family members to raise their professional qualifications and provide help to seek, start and maintain paid employment. ${ }^{39}$ The professional role is currently perceived as one of the most important, if not the most important,

${ }^{37}$ Art. 15 item 12 of the act of 9 June 2011 on Family support and system of foster care (Journal of Law 2018 item 998 with changes).

${ }^{38}$ More on the topic of activities that encourage change, model sof social work with a family that displays functioning problems: I. Krasiejko, Zawód asystenta rodziny w procesie profesjonalizacji. Wstęp do teorii i praktyki nowej profesji spotecznej, Toruń 2013; I. Krasiejko, Praca socjalna w praktyce asystenta rodziny. Przykład Podejścia Skoncentrowanego na Rozwiazzaniach, Katowice 2013; J.M. Jaraczewska, I. Krasiejko (Eds.) Dialog motywujacy w teorii i praktyce. Motywowanie do zmiany w pracy socjalnej i terapii, Torun 2012.

${ }^{39}$ Art. 15 item 1 points 7-9 of the act of 9 June 2011 on Family support and system of foster care (Journal of Law 2018 item 998 with changes). 
social role taken up by the individual. Working with the beneficiary in this field should also be based on the principle of subsidiarity previously mentioned in this paper.

Help provided according to this principle has to be based on forms that trigger the potential of the individual and make it possible to use the present yet unconscious strengths and resources. Being aware of the importance of the principle of subsidiarity when working with an individual who benefits from social assistance, supporting them in overcoming life difficulties, activating them, and not simply providing them with help that consists in granting the benefit that was applied for which consolidates a passive attitude, is a very important topic from the perspective of completing the objectives of social assistance. In the modern approach to social work, the client is perceived as one who can manage their own strengths and resources, capable of taking decisions about their life and able to rightfully cooperate in tackling the difficulties. On the other hand, the supporting person is supposed to enter the role of a partner in this relation, a sort of facilitator, ${ }^{40}$ a companion who activates them to the expected change.

Assistance understood in this way should lead to equipping the supported individual with specific competences necessary to take up self-help, enter the social roles assigned and play them in an appropriate, socially expected way. The notion of the social role ${ }^{41}$ is linked to the notion of the social position, i.e. placement of the individual in a given group. Supporting a beneficiary in their entering given social roles can consist in directing them to professional courses and supplementary training, and helping them find employment. It is worth underlining, however, that in some situations the supported person is not ready to take up a challenge consisting in making an effort to find a job. This is because they have problems with interpersonal contacts, do not have the skill to start interactions with other members of the community, do not have the elementary skills necessary in social life, and their professional skills do not match the requirements of the contemporary work market. The family assistant who diagnoses a problem in this respect can direct the person they support to a psychologist or therapist who provides specialized counselling, make it possible for them to participate in workshops that develop social competences, provide them with information and help the client solve the problem. Entering the professional role and working are of immense importance for the individual. Apart from remuneration that allows them to satisfy their

40 T. Kaźmierczak, Czy praca socjalna w Polsce jest nowoczesna? [in:] Współczesne wyzwania i metody pracy socjalnej, Ed. W. Szymczak, Lublin 2009, p. 93.

${ }^{41}$ A social role is defined as a set of rights and duties linked to a given position, and as a scheme of behaviour related to the above-mentioned position (the so-called role script) B. Szacka, Wprowadzenie do socjologii, p. 144-145. 
own and their family's needs and gives them a chance to function without the necessity to use social welfare resources, they gain the sense of professional usefulness and their self-evaluation improves. Cooperating in a group of co-workers or in a team and developing the skill of cooperation also gives rise to the sense of belonging to a given group and solidarity, and requires loyalty and ability to adopt solutions based on compromise. It also has to be underlined that showing the way of performing the professional role by the parent is important for the children that are brought up in the family as it shapes their attitude towards professional work and the social role of the employee.

In case there is such a need, another task of the family assistant is to intervene and find a remedy when the safety of the children and family is at risk, as well as cooperate with an interdisciplinary team or work group. ${ }^{42}$ Their formal activity in this respect is justified if there have been acts of violence or aggression towards the members of the family by another family member (e.g. parent, partner, cohabitee).

In justified cases, for the protection of their well-being and based on a court adjudication, the child is placed away from their natural family in foster care, which has already been mentioned above. It has to be underlined that placing a child in foster care can only happen when other intervention measures in the execution of parental authority ${ }^{43}$ and forms of helping the child's parents ${ }^{44}$ previously applied have not lead to the elimination of the state of threat to the child's well-being. The need to provide the child with foster care can become urgent, however, if there is a serious threat to the child's well-being, in particular a threat to their life or health. ${ }^{45}$

The task of the assistant of a family whose child stays away from it in foster care is to provide the family with correctional work. This notion encompasses a spectrum of activities of educational, psychological and therapeutic character. Working with the family is aimed at changing its perception of the child, their rights and position in the family, and shaping the appropriate attitude towards the child based on respect and acceptance. The child themselves often battles against problems of various nature due to the socialization

${ }^{42}$ Activities that are part of counteracting family violence, rights, responsibilities and work organization of interdisciplinary teams counteracting family violence and problematic work groups are defined in the Act on counteracting family violence of 29 July 2005 (Journal of Law 2015 item 1390 with changes).

${ }^{43}$ Art. 109 § 2 point 1-4 of the Family Law Act of 25 February 1964 (Journal of Law 2017 item 682 with changes).

${ }^{44}$ The measures of support for parents mentioned in the text are described in the Act on Family support and system of foster care of 9 June 2011 (Journal of Law 2018 item 998 with changes).

${ }_{45}$ Art. $1123 \S 1$ of the Family Law Act of 25 February 1964 (Journal of Law 2017 item 682 with changes). 
mistakes made in their upbringing. Sometimes working with parents consists in supporting them in achieving competences that are crucial for bringing up their child: reliability and responsibility for their actions and course of the upbringing process.

If problems with fulfilling parental duties correctly result from an addiction in the family or addiction-related mental disorders, the family assistant can make efforts to submit the addicted parent to treatment or addiction therapy, or initiate diagnostic and treatment procedures related to the protection of mental health. ${ }^{46}$ Actions aimed at diagnosing the addiction and starting treatment and therapy are taken with the approval of the social welfare centre that operates where the family lives as part of the procedures carried out by the county commission for solving alcohol problems. ${ }^{47}$

Together with the family members and foster care coordination, the family assistant designs a plan of work with the family that is coordinated with the plan of assistance for the child placed in foster care. This two-way character of the corrective and assistance actions targeted at the natural family temporarily deprived of their child custody on the one hand, and at the child who remains in foster care on the other, is by all means important and necessary. It allows for social work with the family, motivating parents to take up activities aimed at "regaining their child", including a therapy, treatment, developing indispensable competences, as well as it makes it possible for the natural family and the child placed away from it to have contact. This contact makes it possible to maintain and keep the emotional bond between the parent and the child, stimulates the parent to change their way of life and behaviour, and gives the child hope that they will return to their home that will function correctly. However, efforts made in this respect do not always lead to the improvement of the family functioning, social roles being taken up or performed correctly by it. As it happens, even though supported and activated, parents who act on their free will do not change their conduct towards children, do not want or are not able to make the effort to bring them back home. In such cases, in order to keep the emotional bond between the child and their parents, it is important for the natural family and foster care

${ }^{46}$ Activities related to diagnosing and treating mental disorders, the procedure for sending a person in need for treatment, the rights in this respect of social welfare institutions, and the family assistant who operates as part of them, are defined in the Act on mental heath of 19 August 1994 (Journal of Law 2018 item 1878 with changes).

47 According to the regulations of the Act on upbringing in sobriety and counteracting alcoholism of 26 October 1982 (Journal of Law 2018 item 2137 with changes), it is county commissions for solving alcohol problems in particular that initiate action for preventing, solving alcohol problems and integrate those addicted to alcohol with the society. As part of their activities, they also take up action aimed at adjudicating a person addicted to alcohol with the obligation to undergo treatment in a drying-out facility. 
environment to cooperate and have contact, which the family assistant who works with the natural family can encourage them to.

In order to provide the family with professional and effective support, the assistant undertakes cooperation with units of state and local government, non-governmental organizations, and other entities and people specializing in activities for the benefit of children and families. ${ }^{48}$ There is a whole network of institutions and entities that ensure holistic assistance for families that experience problems related to performing educational functions, from family and juvenile courts, to educational institutions, social services, healthcare entities, to non-profit organizations that provide help as part of their statutory activities. It is crucial for the cooperation among them to be based on information exchange and joint assistance planning that uses professional knowledge and experience of each specialist. Reality, however, shows a number of deficiencies as far as effective and constructive cooperation among institutions of the prevention and resocialization system is concerned.

When cooperating with the family court that asks them to do so, the family assistant prepares opinions about the family and their members ${ }^{49}$. These opinions are taken into account when decisions are made by courts on the topic of executing parental authority, limiting it or depriving one of it. They provide substantive support for the court's statements as they include facts and conclusions based on them about the pedagogical and psychological aspects of the family functioning.

All the actions taken towards families that are submitted to assistance have to be listed in the documentation prepared by the family assistant, which allows one to keep trace of the course of cooperation, forms of the interactions applied and evaluations of the progress that results from the activities undertaken.

One of the tasks of the family assistant imposed by the law is the periodic assessment of the family situation and sharing it with the entity that organizes work with the family. ${ }^{50}$ Conclusions from the evaluation make it possible to choose the direction of further work with the family and can be a basis for the decision to change the types of measures of limiting parental authority applied, to restore parental authority or to deprive parents of their authority. They are important for evaluating the legitimacy of taking up further actions of external interference in the educational system of the family.

\footnotetext{
${ }^{48}$ Art. 15 item 1 point 18 of the act of 9 June 2011 on Family support and system of foster care (Journal of Law 2018 item 998 with changes).

${ }_{49}$ Art. 15 item 1 point 17 of the act of 9 June 2011 on Family support and system of foster care (Journal of Law 2018 item 998 with changes).

${ }^{50}$ The evaluation discussed is carried out at least once every half a year - art. $15 \mathrm{item} 1$ point 15 of the act of 9 June 2011 on Family support and system of foster care (Journal of Law 2018 item 998 with changes).
} 
In order to maintain the effect of their work achieved, the family assistant is obliged to monitor how the family functions after it has finished working with them. ${ }^{51}$ If need be, the monitoring allows to resume assistance activities, in case the family starts to demonstrate a problem with carrying out the tasks it was assigned with.

The assistant's work with the family can provide assistance, support, control, activation, education and correction. Depending on the need diagnosed, work with one family can be characterized with assistance and control, whereas working with another will be based on activation and corrective education. It is important to prevent and counteract the progress of the process of social maladjustment of children at the early stage of symptoms that indicate their social maladjustment or demoralization. It is necessary for the family to cooperate with institutions of the prevention and resocialization system that operate where the family lives.

\section{Conclusion}

Taking the above considerations into account, one has to state that the work of the family assistant is a set of different activities of legal, pedagogical and psychological character. The assistant's work with parents who do not perform their functions appropriately is an element of the institutional system of prevention and support. It consists in supporting parents in their overcoming problems related to upbringing their offspring, helping them tackle life and professional difficulties, and activating them in order for them to achieve new indispensable competences. The assistant's activities are targeted at motivating parents to undertake correct custody over their child, which influences the correct course of the process of the child's socialization and counteracts their social maladjustment.

The effective completion of the tasks imposed by the family assistant, based on intentional and directed actions, requires, however, broad interdisciplinary knowledge from various fields of social work, psychology, sociology and law. It also requires diagnostic and analytical skills, ability to observe and modify the measures and actions applied, knowledge in material law and procedures that define the formal functioning of given entities of the social support system. Based on one's broad knowledge, good practices and compliance with the law, the family assistant's activity and cooperation with other institutions of the system of prevention and assistance, such as family courts, social welfare centres, entities of the system of education and healthcare make

${ }^{51}$ Art. 15 item 1 point 16 of the act of 9 June 2011 on Family support and system of foster care (Journal of Law 2018 item 998 with changes). 
it possible to provide the family with multifaceted help in order to change the way it functions. As a result, it leads to positive educational influence on the children that are brought up in the family.

\section{BIBLIOGRAPHY}

Andrzejewski M., Prawo rodzinne i opiekuńcze, Warszawa 2014.

Cęcelek G., Rodzina - jej problemy oraz zagrożenia wychowawcze, Mazowieckie Studia Humanistyczne, 2005, 1-2.

Harris J.R., Geny czy wychowanie? Co wyrośnie z naszych dzieci i dlaczego, transl. A. Polkowski, Warszawa 1998.

Harwas-Napierała B., Rodzina jako wartość w rozwoju człowieka, Poznań 2009.

Hurrelmann K., Struktura społeczna a rozwój osobowości. Wprowadzenie do teorii socjalizacji, Poznań 1994.

Jaraczewska J.M., Krasiejko I. (Eds.), Dialog motywujący w teorii i praktyce. Motywowanie do zmiany w pracy socjalnej i terapii, Torun 2012.

Kaźmierczak T., Czy praca socjalna w Polsce jest nowoczesna? [in:] Wspótczesne wyzwania i metody pracy socjalnej, Ed. W. Szymczak, Lublin 2009.

Konstytucja Rzeczpospolitej Polskiej z 2 kwietnia 1997 r. (DzU 1997, nr 78, poz. 483).

Krasiejko I., Nowa rola asystenta rodziny, [in:] Pomoc spoteczna wobec rodzin. Interdyscyplinarne rozważania o publicznej trosce o dziecko i rodzinę, Ed. D. Trawkowska, Torun 2011.

Krasiejko I., Praca socjalna w praktyce asystenta rodziny. Przykład Podejścia Skoncentrowanego na Rozwiazaniach, Katowice 2013.

Krasiejko I., Zawód asystenta rodziny w procesie profesjonalizacji. Wstęp do teorii i praktyki nowej profesji społecznej, Toruń 2013.

Lalak D., Pilch T. (Eds.), Elementarne pojęcia pedagogiki społecznej i pracy socjalnej, Warszawa 1999.

Modrzewski J., Konformizm i dewiacja w doświadczeniu socjalizacyjnym jednostek $i$ w ich spotecznej kwalifikacji, [in:] Socjalizacja dysocjacyjna w doświadczeniu indywidualnym i społecznym. Inspiracje teoretyczne i próby pedagogicznych ingerencji, Eds. A. Matysiak-Błaszczyk, J. Modrzewski, Poznań - Kalisz 2012.

Nikitorowicz J., Rodzina w procesie ksztattowania tożsamości kulturowej w dobie regionalizacji i globalizacji, [in:] Wspótczesne rodziny polskie - ich stan i kierunek przemian, Ed. Z. Tyszka, Poznań 2004.

Rajewska de Mezer J., Rola poradnictwa specjalistycznego we wsparciu rodziny w funkcji wychowawczej, [in:] Młodzież między ochroną a ryzykiem. Wspieranie rozwoju oraz pomoc psychologiczno-pedagogiczna dla adolescentów i adolescentek, Eds. B. Jankowiak, A. Matysiak-Błaszczyk, Poznań 2017.

Sierpowska I., Ustawa o pomocy społecznej. Komentarz, Warszawa 2007.

Szacka B., Wprowadzenie do socjologii, Warszawa 2003.

Szlendak T., Socjologia rodziny. Ewolucja, historia, zróżnicowanie, Warszawa 2012.

Sztompka P., Socjologia. Analiza społeczeństwa, Kraków 2003.

Świderska M., Asystent rodziny - współczesna forma pomocy rodzinie, Łódź 2013.

Trost J., Family from a Dyadic Perspective, Journal of Family Issues, 1993, 14, 1.

Ustawa z 25 lutego 1964 r. Kodeks rodzinny i opiekuńczy (DzU 2017, poz. 682 ze zm.).

Ustawa z 26 października 1982 r. o wychowaniu w trzeźwości i przeciwdziałaniu alkoholizmowi (DzU 2018, poz. 2137 ze zm.). 
Ustawa z 19 sierpnia 1994 r. o ochronie zdrowia psychicznego (DzU z 2018, poz. 1878 ze $\mathrm{zm}$.).

Ustawa z 12 marca 2004 r. o pomocy społecznej (DzU z 2018, poz 1508 ze zm.).

Ustawa z 29 lipca 2005 r. o przeciwdziałaniu przemocy w rodzinie (DzU z 2015, poz. 1390 ze $\mathrm{zm}$.).

Ustawa z 9 czerwca 2011 r. o wspieraniu rodziny i systemie pieczy zastępczej (DzU 2018, poz. 998 ze zm.).

Wysocka E., Warsztat diagnostyczny pracownika socjalnego w obszarze pracy z rodzina oraz przedmiotowe i podmiotowe uwarunkowania procesu diagnozy środowiska rodzinnego, [in:] Pomoc społeczna wobec rodzin. Interdyscyplinarne rozważania o publicznej trosce o dziecko i rodzine, Ed. D. Trawkowska, Torun 2011.

Żurek A., Swoi i obcy w rodzinie, [in:] Rodzina wobec wyzwań wspótczesności. Wybrane problemy, Eds. I. Taranowicz, S. Grotowska, Wrocław 2015. 